\title{
Estudio epidemiológico de las urgencias en cirugía oral y maxilofacial en un hospital general
}

\author{
Epidemiological study of oral and maxillofacial emergencies \\ in a general hospital
}

\author{
B. Peral Cagigal', F.J. Barrientos Lezcano', M. Galdeano Arenas', \\ L.A. Sánchez Cuéllar², A. Verrier Hernández ${ }^{3}$
}

Resumen: Objetivo. La demanda de asistencia en los Servicios de Urgencias Hospitalarias está en constante crecimiento desde hace varias décadas y en especial en la Cirugía Maxilofacial. El objetivo de este estudio es realizar un análisis epidemiológico de las urgencias que se producen en dicha especialidad.

Diseño del estudio. Estudio transversal y observacional de pacientes atendidos por Cirugía Maxilofacial en el Servicio de Urgencias del Hospital Río Hortega de Valladolid durante el año 2002. Se analizaron 1.970 pacientes y 10 variables.

Resultados. Se atendieron 1.970 pacientes, de los cuales el 55,8\% fueron hombres. La mayor presión asistencial se produjo en domingo $(15,8 \%)$ y en el mes de junio (10,9\%). El rango de edad con mayor demanda asistencial fue de los 0 a los 10 años (22,6\%). La etiología más común por la que los pacientes fueron atendidos resultaron ser los accidentes $(55,1 \%)$ y el grupo diagnóstico los traumatismos $(55,6 \%)$. El tipo de tratamiento inmediato más frecuente fue el médico (58,5\%). Fueron ingresados el 9,4\% de los pacientes y revisados en consulta un 33,1\%. El 90,3\% de los pacientes pertenecían al área del hospital.

Conclusiones. El rango de edad más frecuente de los pacientes atendidos es de 0 a 10 años y la mayoría de los pacientes que acuden a urgencias son hombres.

El día con mayor presión asistencial es el domingo y el mes con mayor número de urgencias y de ingresos es junio. La etiología por la que acuden más frecuentemente a urgencias son los accidentes y la traumatología configura la patología maxilofacial con mayor demanda de atención urgente en nuestro hospital. El tratamiento más frecuente es el médico.

Palabras clave: Estudio epidemiológico; Urgencias; Cirugía Maxilofacial.

\begin{abstract}
Objective. The demand placed on emergency care units continues to increase at a growing rate, in special Maxillofacial Surgery. The objective of the study is to perform an epidemiological analyses in the emergency maxillofacial area.

Design. Transversal observational study of the patients attended in the maxillofacial department in the Rio Hortega Hospital's Emergency Services during one year (2002). 1.970 patients and 10 variables were analysed.

Results. 1.970 patients were attended. Males (55,8\%) were predominant all over females. The month of highest incidence was June $(10,9 \%)$ and the day of the week Sunday $(15,8 \%)$. The dominant group of age was $0-10$ years $(22,6 \%)$.

Most common aetiology was the accidents $(55,1 \%)$ and the diagnosis was maxillofacial trauma (55,6\%). The treatment was medical in $58,5 \%$ of cases. Hospital admissions rate was $9,4 \%$ and a 33,1\% need a revisions. The rate of patients in our hospital area was $90,3 \%$.

Conclusions. The age's rank more common in patients attended was between 0-10 years and most of them were male. The day with more assistencial demand was Sunday and the month June. The aetiology for assistance was accidents and traumatism was the principal diagnosis in our hospital. The treatment usually was medical.
\end{abstract}

Key words: Epidemiologic study; Emergency; Maxillofacial Surgery.
1 Médico Residente.

2 Médico Adjunto.

3 Jefe de Servicio.

Servicio Regional de Cirugía Oral y Maxilofacial.

Hospital Universitario del «Río Hortega». Valladolid. España.
Correspondencia:

Dra. Peral Cagigal

Servicio Regional de Cirugía Oral y Maxilofacial,

Hospital Universitario del Río Hortega,

C/ Cardenal Torquemada s/n, 47010 Valladolid, España.

E-mail: beaperal77@yahoo.es 


\section{Introducción}

La demanda de asistencia en los Servicios de Urgencias Hospitalarias está en constante crecimiento desde hace varias décadas y en especial en la Cirugía Maxilofacial. Se efectúa el estudio en el Servicio de Urgencias del Hospital Río Hortega de Valladolid. Este es un hospital dependiente del SACYL (Servicio de Salud de Castilla y León), con 539 camas, que atiende a una población aproximada de 235.000 habitantes, la correspondiente a Valladolid Oeste (aunque su zona geográfica de referencia es toda Castilla y León en el caso de Cirugía Oral y Maxilofacial).

La Cirugía Oral y Maxilofacial se define por la Comisión Nacional de la Especialidad como una especialidad médico-quirúrgica que se ocupa de la prevención, estudio, diagnóstico, tratamiento y rehabilitación de la patología de la cavidad bucal y de la cara, así como de estructuras cervicales relacionadas directa o indirectamente con las mismas.

Es importante tener en cuenta la calidad asistencial dentro de la Cirugía Oral y Maxilofacial, de forma que el enfermo perciba la asistencia como efectiva, accesible, aceptable y útil, sin olvidar la importancia de una información adecuada. Alcanzaremos así una satisfactoria relación del paciente-usuario con el sistema sanitario. ${ }^{1}$

El Servicio de Urgencias es uno de los más complejos y con mayor demanda asistencial en cualquier centro hospitalario. A diferencia de otros niveles de atención hospitalaria, la presión asistencial con la falta de tiempo que conlleva para una adecuada valoración clínica y la premura para adoptar decisiones que agilicen el funcionamiento del Servicio son factores que condicionan la actuación en urgencias. $^{2}$

En el caso particular del Hospital Universitario del Río Hortega, el Servicio de Urgencias ofrece una primera atención en el llamado «filtro», donde las urgencias son catalogadas según un nivel de prioridad, de forma que los pacientes sean atendidos según el grado de urgencia de su caso con independencia del orden de llegada, y remitidos a un especialista si se considera pertinente. Es decir, se realiza un triaje de los pacientes que acuden a dicho Servicio.

Durante el año 2002, fueron atendidas un total de 93.311 personas en el Servicio de Urgencias de nuestro hospital, de ellas 1.970 fueron atendidas por el Servicio de Cirugía Oral y Maxilofacial, lo que supone un $2,1 \%$ del total.

En la literatura nacional e internacional existen diversas publicaciones en las que se describen estudios epidemiológicos de los pacientes que acuden a los Servicios de Urgencias llevados a cabo en diferentes poblaciones. ${ }^{3,4}$

También se han realizado estudios de éste tipo en nuestra Comunidad Autónoma, y concretamente en nuestro hospital, ${ }^{5}$ pero analizando de forma general las urgencias hospitalarias, por lo que nos planteamos realizar un estudio más específico referente a las urgencias en la Cirugía Oral y Maxilofacial.

\section{Material y método}

Se incluyeron en el estudio todos los pacientes que acudieron al Servicio de Urgencias del Hospital Universitario del Río Hortega

\section{Introduction}

The demand for assistance by hospital emergency services has been growing constantly for various decades and especially in Maxillofacial Surgery. The study was carried out in the Emergency Unit of the "Hospital Rio Hortega» in Valladolid. This hospital depends on the SACYL (Health Service of Castilla and León), with 539 beds, which attends a population of approximately 235.000 inhabitants, corresponding to western Valladolid (even though the geographical area of reference is the whole of Castilla and León in the case of Maxillofacial Surgery.

Oral and Maxillofacial Surgery has been defined by the National Commission of Specialties as a medical-surgical specialty that deals with the prevention, study, diagnosis, treatment and rehabilitation of the pathology of the oral cavity and face, as well as with cervical structures that are directly or indirectly related.

It is important to bear in mind the quality of assistance within Oral and Maxillofacial Surgery, so that the patient sees the assistance as effective, accessible, acceptable and useful, without forgetting the importance of providing adequate information. In this way a satisfactory patient-user relationship with the health system will be reached.'

The Emergency Unit is one of the most complex departments having the greatest demand for assistance within hospital centers. Unlike other levels of hospital attention, the pressure on assistance together with the time it takes to carry out a proper clinical evaluation, and the pressure to adopt decisions that will make the Service operate faster, are factors which condition performance during emergencies. $^{2}$

In the case of the "Hospital Universitario Rio Hortega», the Emergency Unit offered initial attention at the so called «filter» point, where the emergencies are categorized according to a level of priority, so that patients are attended according to the degree of urgency of their case, independent of the order in which they arrive, and they are sent to a specialist if considered appropriate. That is to say, the patients that attend this Service are screened.

During 2002, a total of 93.311 patients were attended by the Emergency Unit in our hospital. Of these 1.970 were attended by the Service of Maxillofacial Surgery, which represented $2.1 \%$ of the total.

In the national and international literature there are several publications describing Epidemiologic studies of patients that attend the Emergency Services of different localities. ${ }^{3,4}$

Studies of this type have been carried out in our Autonomous Community, and to be more exact, in our hospital5, but medical emergencies have been analyzed in a general way. We therefore decided on a more specific study with regard to emergencies in Maxillofacial Surgery. 
de Valladolid durante el año 2002 que fueron atendidos por el cirujano oral y maxilofacial de guardia.

Se excluyeron del estudio las urgencias intrahospitalarias derivadas de los pacientes ingresados en Cirugía Maxilofacial o en cualquier otra especialidad, así como los pacientes con urgencias leves atendidos por el staff de urgencias. Se incluyeron un total de 1.970 pacientes.

Recogida de datos: El estudio se realizó de forma transversal y observacional, recogiéndose las siguientes variables: día de la semana, mes, edad, sexo, grupo etiológico, grupo diagnóstico, tratamiento inmediato, ingreso en Cirugía Maxilofacial, revisión en consulta externa y origen del paciente.

El estudio estadístico se llevó a cabo utilizando el programa SPSS 10,0 y se realizó un estudio descriptivo de los datos, hallando tablas de frecuencia y de contingencia.

\section{Resultados}

Durante el año 2002 fueron atendidos un total de 93.311 pacientes en Urgencias, de los cuales 1.970 fueron valorados por el cirujano oral y maxilofacial, lo que supone un $2,1 \%$ del total de pacientes atendidos y una media de 5,39 pacientes/día.

Un total de 15.915 personas fueron ingresadas en nuestro hospital a través del Servicio de Urgencias durante el año 2002, lo que supone un $17,06 \%$ del total de pacientes atendidos. De ellos, 185 fueron ingresados por Cirugía Maxilofacial, lo que supone el 1,2\% del total de pacientes ingresados y el 9,4\% del total de pacientes atendidos por el cirujano maxilofacial.

Sexo. De los 1.970 pacientes atendidos por Cirugía Maxilofacial durante el año 2002 , el $55,8 \%$ fueron hombres $(n=1.100)$ y un $44,2 \%$ mujeres $(n=870)$.

Fueron ingresados un total de 185 pacientes, de los cuales el $70,8 \%$ eran hombres $(n=131)$ y el $29,2 \%$ eran mujeres $(n=54)$.

Las urgencias debido a heridas $y / 0$ traumatismos faciales fueron más frecuentes en hombres $(61,7 \%)$ que en mujeres $(38,3 \%)$.

El $93,7 \%$ de los pacientes que acudieron a Urgencias debido a un accidente laboral, el $71,2 \%$ de los atendidos por un accidente de tráfico y el $82,6 \%$ de los pacientes que habían sufrido una agresión eran hombres (con $n=30, n=94$ y $n=62$ respectivamente).

En el resto de grupos diagnósticos apenas hay diferencias entre hombres y mujeres, a excepción de las urgencias derivadas de la articulación temporomandibular donde el $74,6 \%$ de los pacientes fueron mujeres $(n=53)$.

Edad de los pacientes. El rango de edad con mayor demanda asistencial fue de los 0 a los 10 años con un 22,6\% del total $(n=445)$. El segundo grupo de edad en frecuencia fue de 21 a 30 años con un $21,2 \%(n=418)$.

El grupo de edad entre los 21 y 30 años fue en el que más ingresos se registraron ( $n=52$, el $28,1 \%$ del total) y también el que más necesitó una revisión en consulta $(27,4 \%$ del total de pacientes vistos en consulta; $\mathrm{n}=179$ ).

La Figura 1 muestra la distribución según el sexo y la edad de los pacientes atendidos en Urgencias.

\section{Material and method}

All the patients that came to the Emergency Unit in the «Hospital Universitario Rio Hortega», Valladolid during the year 2002 and that were attended by the Maxillofacial Surgeon on duty, were included in the study.

Emergencies related to patients already admitted for Maxillofacial Surgery or any other specialty were excluded, as well as patients with minor emergencies that were attended by staff in the Emergency area. A total of 1.970 patients were included.

Data collection: The study was carried out in a transversal and observational mode and the following variables were taken into account: day of the week, month, age, gender, etiological group, dignostic group, immediate treatment, admission into Maxillofacial Surgery, external follow-up care and origin of the patient.

The statistical study was carried out using the SPSS 10.0 program and a descriptive study was carried out with the data. Frequency and contingency tables could then be drawn up.

\section{Results}

During the year 2002 a total of 93.311 patients were attended by the Emergency Unit, of which 1.970 were evaluated by the Maxillofacial Surgeon, which represented 2.1\% of the total number of patients attended, and an average of 5.39 patients per day.

A total of 15.915 people were admitted into our hospital through the Emergency Unit during the year 2002, which represented $17.6 \%$ of the total of patients attended. Of these 185 were admitted for Maxillofacial Surgery, which represented $1.2 \%$ of the total number of patients admitted and $9.4 \%$ of the total number of patients attended by the Maxillofacial Surgeon.

Gender. Of the 1.970 patients attended in the Maxillofacial Surgery Unit during 2002, 55.8\% were men ( $n=$ $1.100)$ and $44.2 \%$ women $(n=870)$.

A total of 185 patients were attended, of which $70.8 \%$ were men $(n=131)$ and $29.2 \%$ were women $(n=54)$.

Emergencies due to wounds and/or facial trauma were more frequent in men (61.7\%) than in women (38.3\%).

Men made up $93.7 \%$ of the patients that attended the Emergency Unit due to accidents at work, $71.2 \%$ of those attended because of traffic accidents, and $82.6 \%$ of patients that had suffered an aggression were men ( $n=30, n=94$ and $n=62$ respectively).

In the rest of the diagnostic groups there were hardly any differences between males and females, with the exception of emergencies derived from the temporomandibular joint, in which $74.6 \%$ of the patients were women. $(n=53)$.

Age of the patients. The 0-10 age group demanded most assistance, representing $22.6 \%$ of the total $(n=445)$. The 
Día de la semana. La asistencia por día de la semana reflejó que la mayor presión asistencial se produjo el domingo $(15,8 \%$; $\mathrm{n}=311)$, y la menor el lunes $(13,5 \%$; $=$ 265).

El día de la semana con mayor número de ingresos registrados fue el jueves $(18,9 \% ; n=35)$, seguido de los domingos $(15,7 \% ; n=29)$.

Los hombres acudieron a Urgencias más en domingo $(16,7 \% ; \mathrm{n}=184)$ y las mujeres en viernes $(15,7 \% ; n=137)$.

Las lesiones por accidentes de tráfico fueron más frecuentes en viernes (21,9\% del total de accidentes) y de las agresiones en domingo (24\%).

Mes. El mes con mayor número de urgencias fue junio con un $10,9 \%$ del total $(n=214)$, seguido de marzo con un $9,7 \%(n=192)$, y el menor fue agosto con un $6,4 \%(n=126)$.

La media de pacientes atendidos por Cirugía Maxilofacial en un mes es de 164,2 pacientes / mes. La Figura 2 muestra la distribución de pacientes atendidos cada mes.

El mes de junio fue también el mes con mayor número de ingresos $(n=28$, el $15,1 \%$ del total), y noviembre el mes en el que menos ingresos se realizaron $(3,2 \% ; \mathrm{n}=6)$.

El mes con más accidentes laborales fue mayo ( $21,8 \%$ del total ; $n=7)$, con más accidentes de tráfico fue junio $(14,4 \%$; $\mathrm{n}=19)$ y el mes con más agresiones fue septiembre $(16 \% ; \mathrm{n}=12)$.

Etiología. El 55,1\% acudieron al Servicio de Urgencias debido a accidentes y otras lesiones y el $44,9 \%$ fueron atendidos por enfermedad. La tabla 1 muestra la distribución de las distintas etiologías por las que los pacientes acudieron a Urgencias.

La causa más frecuente de las heridas y contusiones cérvicofaciales fueron los accidentes casuales (en el $77,7 \%$ de los casos), igual que de las fracturas de los huesos faciales $(60,4 \%)$. Las agresiones produjeron principalmente heridas y contusiones cérvicofaciales $(54,7 \% ; n=41)$ y fracturas mandibulares $(20 \% ; n=15)$.

La causa más frecuente por la que acudieron a Urgencias los pacientes de 0 a 10 años fueron los accidentes casuales $(n=385$; $45,5 \%) ; y$ los pacientes entre 21 y 30 años lo hicieron por enfermedad ( $n=259 ; 29,2 \%)$.

Diagnóstico. Los pacientes fueron divididos en 8 grupos diagnósticos principales, siendo los traumatismos el diagnóstico más frecuente en Urgencias $(55,6 \% ; n=1093)$ seguido por el grupo de urgencias odontológicas $(20,2 \% ; n=397)$. La Tabla 2 muestra la distribución en porcentaje de los diferentes grupos diagnósticos.

Las urgencias odontológicas, las infecciones cérvico-faciales y los trastornos de la articulación temporomandibular son más frecuentes de 21 a 30 años. second most frequent age group was the 21 to 30 group with $21.2 \%(n=$ 418).

The 21 to 30 age group had the most admissions ( $n$ $=52,28.1 \%$ of the total) and the group that most needed follow-up care $27.4 \%$ of the total number of patients seen for consultation; $(n=179)$. Figure 1 gives a breakdown according to the gender and age of the patients treated in the Emergency Unit.

Day of the week. The rate of assistance according to the day of the week reflected that the greatest pressure was produced on Sundays $(15.8 \% ; n=311)$, and the least on Mondays $(13.5 \% ; n=265)$.

The day of the week registering the greatest number of patient admissions was Thursday (18.9\%; $n=35)$, followed by Sunday $(15.7 \% ; n=29)$.

Men attended the Emergency Unit more on Sundays $(16.7 \% ; n=184)$ and women on Fridays $(15.7 \% ; n=137)$.

Lesions from traffic accidents were more frequent on Fridays (21.9\% of the accident total) and from aggressions it was Sunday (24\%).

Month. The month with the largest number of emergencies was June with $10.9 \%$ of the total $(n=214)$, followed by March with 9.7\% $(n=192)$, and the lowest was August with $6.4 \%(n=126)$.

The average number of patients attended for Maxillofacial Surgery in a month was of 164.2 patient/month. Figure 2 shows the breakdown of patients attended every month.

The month of June was the month with the greatest number of admissions ( $n=28,15.1 \%$ of the total), and November the month that had the least number of admissions $(3,2 \% ; n=6)$.

The month with most work related accidents was May $(21.8 \%$ of the total; $n=7)$, with most traffic accident was June $(14.4 \% ; n=19)$ and the month with most aggressions was September $(16 \% ; n=12)$.

Etiology. 55.1\% attended the Emergency Unit due to accidents and other lesions, and $44.9 \%$ were attended for illness. Table 1 shows the breakdown of the different eti- 
El $42,5 \%$ de las heridas faciales se producen en niños de 0 a 10 años $(n=350)$ y el $21,1 \%$ de las fracturas faciales se dan en el grupo de edad de 21 a 30 años ( $n=57)$.

El diagnóstico más frecuente en los pacientes trasladados desde otros hospitales también fueron las heridas y traumatismos cérvico-faciales; el Hospital Clínico Universitario de Valladolid trasladó durante el año 2002 un total de 101 pacientes de los cuales 66 fueron por heridas $y$ traumatismos (65,3\%).

La fractura más frecuente fue la fractura mandibular $(\mathrm{n}=104$; $53 \%$ ) seguido de las fracturas dentoalveolares y traumatismos dentarios.

Tratamiento. El tipo de tratamiento inmediato que se llevó a cabo fue tratamiento médico en un $58,5 \%(n=1.153)$, quirúrgico con anestesia local en un $41 \%(n=807)$ y quirúrgico con anestesia general en un $0,5 \%$ $(n=10)$.

El tratamiento médico fue el tratamiento prioritario en las odontalgias e infecciones odontológicas $(20,9 \%$ del total de casos en los que se instauró tratamiento médico; $\mathrm{n}=241$ ).

El tratamiento quirúrgico con anestesia local fue utilizado principalmente en las heridas cérvico-faciales $(72,5 \%$ del total de casos en los que se realizó este tratamiento; $\mathrm{n}=585$ ).

El tratamiento quirúrgico con anestesia general fue necesario sobre todo en pacientes con heridas cérvico-faciales (30\% del total de pacientes intervenidos bajo anestesia general; $\mathrm{n}=3$ ).

Ingresos. Del total de pacientes atendidos durante el año 2002 fueron ingresados en el hospital 185 pacientes, de los cuales 118 pertenecían a nuestra área hospitalaria y 67 fueron trasladados desde otros hospitales; el Hospital Clínico Universitario de Valladolid fue el hospital que más ingresos generó, con un $22,4 \%$ del total de ingresos originados por traslados $(n=15)$.

\section{Etiological group}

Illness

Fortuitous accident

Accident at work

Traffic accident with car or lorry

Traffic accident with motorbike

Traffic accident, run down pedestrian

Agression

Autolysis attempt

Total

\section{Diagnosis}

Dental emergencies

Cervicofacial infections

Cystic tumor pathology

Temporomandibular joint disorder

Trauma

Salivary pathology

Postsurgical complications

Non-classifiable pathologies

Total

Tabla 1. Distribución según grupo etiológico de los pacientes atendidos

$\begin{array}{lcc}\text { Grupo etiológico } & \text { Frecuencia } & \text { Porcentaje } \\ \text { Enfermedad } & 884 & 44,9 \\ \text { Accidente casual } & 846 & 42,9 \\ \text { Accidente laboral } & 32 & 1,6 \\ \text { Accidente de tráfico con coche o camión } & 117 & 5,9 \\ \text { Accidente de tráfico con moto } & 9 & 0,5 \\ \text { Accidente de tráfico por atropello } & 6 & 0,3 \\ \text { Agresión } & 75 & 3,8 \\ \text { Intento autolítico } & 1 & 0,1 \\ \text { Total } & 1970 & 100\end{array}$

Table 1. Breakdown according to the etiological group of the patients attended

Tabla 2. Distribución de los pacientes según grupos diagnósticos

$\begin{array}{lcc}\text { Diagnóstico } & \text { Frecuencia } & \text { Porcentaje } \\ \text { Urgencias odontológicas } & 397 & 20,2 \\ \text { Infecciones cérvicofaciales } & 131 & 6,6 \\ \text { Patología quística-tumoral } & 81 & 4,2 \\ \text { Trastornos articulación temporomandibular } & 71 & 3,6 \\ \text { Traumatismos } & 1093 & 55,4 \\ \text { Patología salivar } & 81 & 4,1 \\ \text { Complicaciones postquirúrgicas } & 42 & 2,1 \\ \text { Patologías no clasificables } & 74 & 3,8 \\ \text { Total } & 1970 & 100\end{array}$

Table 2. Distribution of patients according to the diagnostic groups

$\begin{array}{cc}\text { Frequency } & \text { Percentage } \\ 884 & 44,9 \\ 846 & 42,9 \\ 32 & 1,6 \\ 117 & 5,9 \\ 9 & 0,5 \\ 6 & 0,3 \\ 75 & 3,8 \\ 1 & 0,1 \\ 1970 & 100\end{array}$

$\begin{array}{cc}\text { Frequency } & \text { Percentage } \\ 397 & 20,2 \\ 131 & 6,6 \\ 81 & 4,2 \\ 71 & 3,6 \\ 1093 & 55,4 \\ 81 & 4,1 \\ 42 & 2,1 \\ 74 & 3,8 \\ 1970 & 100\end{array}$

ologies as a result of which the patients attended the Emergency Unit.

The most common cause of wounds and cervicofacial contusions were fortuitous accidents (in $77.7 \%$ of cases), the same as for fractures of facial bones (60.4\%). Aggressions produced mainly wounds and cervicofacial contusions (54.7\%; $n=41)$ and mandibular fractures (20\%; $n=$ 15).

The most common reason for patients in the 0 to 10 age group attending the Emergency Unit were fortuitous accidents ( $n=$ $385 ; 45.5 \%)$ : and for patients between 21 and 30 it was illness ( $n$ = 259; 29.2\%).

Diagnosis. The patients were divided into 8 principal diagnostic groups, trauma being the most frequent diagnosis in the Emergency Unit (55.6\%; $n=$ 1093) followed by dental emergencies (20.2\%; $n=397)$. Table 2 shows the breakdown in percentages of the different diagnostic groups.

Dental emergencies, cervicofacial infections and temporomandibular joint disorders were most common in the 21 to 30 age group. The $42.5 \%$ of facial wounds were produced in children in the 0 to 10 age group $(n=350)$ and $21.1 \%$ of facial fractures occurred in the 21 to 30 age group ( $n=$ 57).

The most frequent diagnosis of the patients transferred from other hospitals were also cervicofacial wounds and trau- 
La Figura 3 muestra la distribución de los pacientes según su destino, domicilio o ingreso, en relación a la edad.

Es decir, el 9,4\% de los pacientes vistos en Urgencias por el cirujano Maxilofacial fueron ingresados $(n=185)$.

La etiología más frecuente de ingreso fueron los accidentes casuales $(33,5 \% ; \mathrm{n}=62)$, seguido de enfermedad $(31,8 \% ; n=59)$ y de los accidentes de tráfico (20\%; $\mathrm{n}=37)$.

La causa más frecuente de ingreso fueron las fracturas mandibulares ( $20 \%$ del total; $\mathrm{n}=37$ ) seguidas de las fracturas órbito-malares $(13,5 \% ; n=25)$.

Revisión. Un 33,1\% de los pacientes valo-

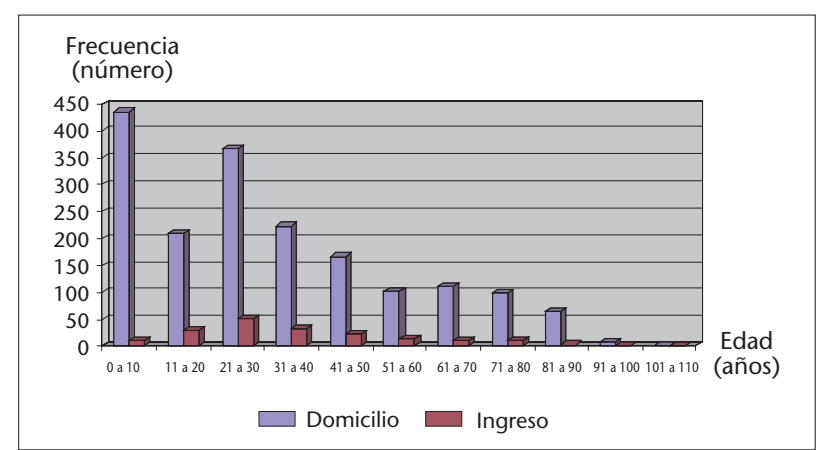

Figura 3. Distribución de los pacientes según su destino, domicilio o ingreso, en cada grupo de edad.

Figure 3. Breakdown according to each age group with regard to outcome, with patients being sent home or admitted. rados en Urgencias fueron revisados posteriormente en la Con-

Tabla 3. Distribución de los pacientes según su hospital de origen sulta de Cirugía Maxilofacial $(n=653)$.

La etiología más frecuente de las revisiones fue por enfermedad $(61,5 \%, \mathrm{n}=402)$.

La patología que originó mayor número de revisiones fueron las odontalgias $y / 0$ infecciones odontológicas (14,2\% del total de pacientes revisados; $\mathrm{n}=93$ ).

Un $55,8 \%$ de los pacientes que acudieron a consulta fueron hombres $(n=365)$.

Origen. El 90,3\% de los pacientes atendidos pertenecían al Hospital del Río Hortega $(n=1.779)$ y el resto fueron trasladados desde otros hospitales $(n=191)$. La Tabla 3 muestra el porcentaje de pacientes trasladados desde los diferentes hospitales de nuestra Comunidad Autónoma.

La etiología más frecuente de los traslados fueron los accidentes casuales $(45,5 \% ; n=87)$ y el rango de edad más frecuente fue de 21 a 30 años(20,9\%; $\mathrm{n}=40$ ). El $58,6 \%$ de los pacien-

\section{Origen del paciente}

Hospital Río Hortega (Valladolid)

Traslado Hospital Clínico Universitario (Valladolid)

Traslado Hospital Medina del Campo (Valladolid)

Traslado Ávila

Traslado Burgos

Traslado León

Traslado Palencia

Traslado Salamanca

Traslado Segovia

Traslado Soria

Traslado Zamora

Total

Table 3. Distribution of patients according to the hospital of origin

\section{Origin of patients}

"Hospital Río Hortega" (Valladolid)

Transfer from "Hospital Clínico Universitario"

(Valladolid)

Transfer from "Hospital Medina del Campo"

(Valladolid)

Transfer from Ávila

Transfer from Burgos

Transfer from León

Transfer from Palencia

Transfer from Salamanca

Transfer from Segovia

Transfer from Soria

Transfer from Zamora

Total tes trasladados fueron hombres ( $n=112$ ) y el diagnóstico más frecuente fueron las heridas y traumatismos cérvicofaciales ( $n=134$; el 70,1\% del total).

\section{Discusión}

En la asistencia hospitalaria urgente es necesario conocer datos epidemiológicos acerca de las personas que la solicitan, de las pato-
Frecuencia Porcentaje

$\begin{array}{cc}1779 & 90,3 \\ 101 & 5,1 \\ 10 & 0,5 \\ 7 & 0,4 \\ 6 & 0,3 \\ 18 & 0,9 \\ 17 & 0,9 \\ 2 & 0,1 \\ 13 & 0,6 \\ 0 & 0 \\ 17 & 0,9 \\ 1970 & 100\end{array}$

ma; the «Hospital Clínico Universitario» of Valladolid transferred during the year 2002 a total of 101 patients, of which 66 were due to wounds and trauma (65.3\%).

The most common fracture was the mandibular fracture ( $n=104$; 53\%) followed by dentoalveolar fractures and dental trauma.

Treatment. The type of treatment given immediately was medical treatment $58.5 \%$ of the time $(n=1.153)$, and surgical with local anesthesia $41 \%(n=807)$ and surgical with general anesthesia in $0.5 \%$ $(n=10)$.

Medical treatment was the main treatment for toothaches and dental infections (20.9\% of the total number of cases requiring medical treatment; $n=241$ ). Surgical treatment with local anesthesia was used principally for cervicofacial wounds (72.5\% of the total number of cases having this treatment; $n=$ 585).

Surgical treatment with general anesthesia was necessary especially in patients with cervicofacial wounds (30\% of the total number of patients operated under general anesthesia; $n=3$ ).

Admissions. Of the total number of patients attended during the year 2002, 185 patients were admitted, of which 118 belonged to our hospital area and 67 were transferred from other hospitals; the «Hospital Clínico Universitario» of Valladolid was the hospital that generated the most admissions, with $22.4 \%$ of the total number of transfer related admissions $(n=15)$.

Figure 3 shows the breakdown of patients depending on 
logías más frecuentemente atendidas y de los tratamientos que se realizan.

Elegimos realizar este tipo de estudio, observacional y transversal, porque permite obtener un buen análisis epidemiológico de las urgencias en el campo de la Cirugía Maxilofacial en nuestra Comunidad, pudiendo compararlo con otros hospitales gracias a la revisión bibliográfica llevada a cabo.

Las personas del sexo masculino acuden, de forma global, con más frecuencia al servicio de urgencias, esta diferencia coincide con los resultados de otras publicaciones. . $^{3,4,6-9}$ Además, el $61,7 \%$ de las heridas y traumatismos se producen en hombres $(n=674)$, lo que también concuerda con otros estudios. ${ }^{11,12}$

El rango de edad con mayor demanda asistencial es de los 0 a los 10 años con un 22,6\% del total, resultado que coincide con algunos trabajos 5 y difiere de otros, 4,6 pero el grupo con mayor número de ingresos es de los 21 a los 30 años.

La asistencia por día de la semana refleja que la mayor presión asistencial se produce el domingo (15,8\%), el mismo resultado que en las publicaciones revisadas. ${ }^{5} \mathrm{El}$ mes con mayor número de urgencias y de ingresos es junio, lo que coincide con otros trabajos. ${ }^{6}$

La etiología por la que acuden más frecuentemente a urgencias son los accidentes y otras lesiones.

La causa más frecuente de fracturas faciales fueron los accidentes casuales ( $n=116 ; 60,4 \%$ ), lo cual difiere de muchos estudios donde la causa más frecuente son los accidentes de tráfico. ${ }^{10-15} \mathrm{La}$ fractura más frecuente fue la fractura mandibular ( $n=104 ; 53 \%)$, lo que coincide con otras publicaciones. ${ }^{14}$

Las urgencias odontológicas, las infecciones cérvico-faciales y los trastornos de la articulación temporomandibular son más frecuentes en el rango de edad de 21 a 30 años. ${ }^{16}$

Las urgencias debidas a trastornos de la articulación temporomandibular son más frecuentes en mujeres $(74,6 \%)$ que en hombres, lo que coincide con varias publicaciones. $17,18,19$

Las heridas faciales y los traumatismos dentarios son más frecuentes en niños de 0 a 5 años, sin embargo el resto de traumatismos faciales también son más frecuentes en personas entre 21 y 30 años, lo que coincide con otros estudios. 11,12 $^{1,12}$

Por tanto, la traumatología y las urgencias odontológicas configuran la patología maxilofacial con mayor demanda de atención urgente en nuestro hospital.

El tratamiento de los enfermos de urgencias maxilofaciales en la mayoría de los casos es médico.

Fueron ingresados 185 pacientes durante el año 2002, lo que supone una tasa de hospitalización del 9,4\%, dato similar a un estudio realizado en nuestro hospital en el año 1994 en el que el porcentaje de ingresos en Cirugía Maxilofacial fue del 11,3\%. ${ }^{5}$ Además, un tercio de los pacientes atendidos en Urgencias van a ser revisados posteriormente en nuestra consulta.

\section{Conclusiones}

Según el estudio realizado en nuestro hospital podemos concluir que: el rango de edad más frecuente de los pacientes atendidos es de 0 a 10 años y la mayoría de los pacientes que acuden a urgencias outcome, whether they were sent home or admitted, according to age.

In short, 9.4\% of patients seen in the Emergency Unit by the Maxillofacial surgeon were admitted $(n=185)$.

The most common etiology leading to admission was fortuitous accidents $(33.5 \% ; n=62)$, followed by illness $(31.8 \% ; n=59)$ and traffic accidents $(20 \% ; n=37)$.

The most common reason for being admitted were mandibular fractures ( $20 \%$ of the total; $n=37$ ) followed by fractures of the orbital rim and cheekbone $(13.5 \%$; $n=25)$.

Follow-up. 33.1\% of patients evaluated in the Emergency Unit received follow-up care by the Maxillofacial Unit ( $n=$ 653).

The most frequent etiology in relation to follow-up visits was illness (61.5\%; $n=402)$. The pathology that resulted in the greatest number of follow-up visits were toothache and dental infections (14.2\% of the follow-up visit total; $n$ =93).

Of the patients that came for follow-up care, $55.8 \%$ were men $(n=365)$.

Origin. $90.3 \%$ of patients attended belonged to the «Hospital Rio Hortega» $(n=1.779)$ and the rest were transfers from other hospitals $(n=191)$. Table 3 shows the percentage of patients transferred from the different hospitals of our Autonomous Community.

The most frequent etiology related to the transfers was fortuitous accidents $(45.5 \% ; n=87)$ and the most frequent age range was 21 to $30(20.9 \% ; n=40)$. Of the patients transferred $58.6 \%$ were men $(n=112)$ and the most frequent diagnosis were wounds and cervicofacial trauma ( $n$ $=134 ; 70.1 \%$ of the total).

\section{Discussion}

With regard to emergency care in hospitals, the epidemiologic data of the individuals requesting it has to be understood, together with the most frequent pathologies attended, and the treatments carried out.

We decided to carry out this type of observational, transverse study because it allows obtaining a good epidemiological analysis of emergencies in the field of Maxillofacial Surgery in our Community, and we were able to compare it with other hospitals as a result of the bibliographic revision carried out.

Overall, it was individuals of the male sex that attended the Emergency Unit more frequently, which coincides with the results of other publications.3,4,6,7-9 In addition, $61.7 \%$ of wounds and trauma were produced in men $(n=674)$, which also corresponds with other studies. ${ }^{11,12}$

The age range requiring most care was the 0 to 10 group representing $22.6 \%$ of the total, which coincides with some studies ${ }^{5}$ and differs from others, 4,6 but the group with the greatest number of admissions was in the 21 to 30 age range. The assistance per day of the week reflects that the greatest 
son hombres. El día con mayor presión asistencial es el domingo y el mes con mayor número de urgencias y de ingresos es junio. La etiología por la que acuden más frecuentemente a urgencias son los accidentes y la traumatología configura la patología maxilofacial con mayor demanda de atención urgente en nuestro hospital. El tratamiento inmediato más frecuentemente realizado es el médico.

\section{Bibliografía}

1. Rodríguez Ruiz JA. Urgencias en Cirugía oral y Maxilofacial. Cádiz : Universidad, Servicio de Publicaciones; Madrid: Stratec Medical 2003;pp.19-23.

2. Plaza S, Álvarez-Sala JL, García T, y cols, El error en el diagnóstico de urgencia. Estudio retrospectivo de 1.223 historias clínicas. An Med Intern 1987;4:171-6.

3. Muiño Miguez A, González Ramallo VJ, Rodríguez de Castro E, y cols, Asistencia en un servicio de urgencias: justificación de las visitas y adecuación de los ingresos. Rev Clin Esp 1988;182:374-8.

4. Castillo M, Huguet J, Cortada L. Estudio del área de urgencias de un hospital general. Grado de adecuación de las visitas. Med Clin (Barc) 1986;87:539-42.

5. Gil González JM, Vaquero Puerta JL, Castrodeza Sanz J. Perfil de la demanda asistencial urgente en un hospital general. Rev Salud Publica Castilla Leon 1994;3: 11-17.

6. Lloret J, Puig X, Muñoz J. Urgencias médicas. Análisis de 18.240 pacientes atendidos en el servicio de urgencias de un hospital general en el período de un año. Med Clin (Barc) 1984;83:135-41.

7. Diego Domínguez F, Franch Nadal J, Alvarez Torices JC, y cols, Urgencias hospitalarias en el área sanitaria de León. Estudio de la repercusión en la atención primaria. Aten Primaria 1990;7:37-43.

8. Jiménez Rubio D, Casanovas Rigall X, Maiqués Galán A, y cols, Utilización de los servicios de urgencias hospitalarios por la población de un centro de atención primaria. Atención Primaria 1988;5:314-7.

9. Gassner R, Tuli T, Hachl O, Rudisch A, Ulmer H. Cranio-maxillofacial trauma: a 10 year review of 9.543 cases with 21.067 injuries. J Craniomaxillofac Surg 2003;31:51-61.

10. Ansari MH. Maxillofacial fractures in Hamedan province, Iran: a retrospective study (1987-2001). J Craniomaxillofac Surg 2004;32:28-34.

11. Aksoy E, Unlu E, Sensoz O. A retrospective study on epidemiology and treatment of maxillofacial fractures. J Craniofac Surg 2002;13:772-5.

12. Ugboko VI, Odusanya SA, Fagade OO. Maxillofacial fractures in a semi-urban Nigerian teaching hospital. A review of 442 cases. Int J Oral Maxillofac Surg 1998; 27:286-9.

13. Rodríguez Ruíz JM, Modelo Pérez A, Garzón L, Budiño S, Córdoba JA, Fortis Sánchez E, y cols, Estudio clínico-epidemiológico de las fracturas orbitocigomáticas y del suelo orbitario en la provincia de Cádiz. Rev Esp Cirug Oral y Maxilof 1999; 21:279-86.

14. Bo B, Gu X, Zhou S. An epidemiologic retrospective study of 1693 maxillofacial injuries. Hua Xi Kou Qiang Yi Xue Za Zhi 1998;16:56-8.

15. van Beek G], Merkx CA. Epidemiology of facial injuries. Ned Tijdschr Tandheelkd 1997;104:414-7.

16. Vollaro S, Michelotti A, Cimino R, Farella M, Martina R. Epidemiologic study of patients with craniomandibular disorders. Report of data and clinical findings. Minerva Stomatol 2001;50:9-14.

17. Wahlund K. Temporomandibular disorders in adolescents. Epidemiological and methodological studies and a randomized controlled trial. Swed Dent J Supp/ 2003;164:2-64.

18. Thilander B, Rubio G, Pena L, de Mayorga C. Prevalence of temporomandibular dysfunction and its association with malocclusion in children and adolescents: an epidemiologic study related to specified stages of dental development. Angle Orthod 2002;72:146-54.

19. Phillips JM, Gatchel RJ, Wesley AL, Ellis E. Clinical implications of sex in acute temporomandibular disorders. J Am Dent Assoc 2001;132:49-57. pressure for attention was produced on Sundays (15.8\%), which is the same result that appears in the publications revised. ${ }^{5}$ The month with the greatest number of emergencies and admissions was June, which coincides with other works. ${ }^{6}$

The etiology resulting in more demand for emergency care was accidents and other lesions.

The most frequent cause of facial fractures was fortuitous accidents ( $n=116 ; 60.4 \%)$, which differs from other studies in which the most common cause was traffic accidents. 10-15 The most common fracture was the mandibular fracture $(n=104 ; 53 \%)$, which coincides with other publications. ${ }^{14}$ Dental emergencies, cervicofacial infections and temporomandibular joint disorders were the most frequent in the 21 to 30 age range. ${ }^{16}$

Emergencies due to temporomandibular disturbances were more frequent in women (74.6\%) than in men, which coincides with various publications. ${ }^{17-19}$

Facial wounds and dental trauma were more common in children in the 0 to 5 age range. However, the remaining facial trauma cases were also more frequent in people between the ages of 21 to 30, which coincides with other studies. ${ }^{11,12}$

Therefore, trauma and dental emergencies represent the maxillofacial pathology requiring most emergency care in our hospital.

Patient treatment for maxillofacial emergencies in most cases was medical.

During the year 2002, 185 patients were admitted, which represents a hospitalization rate of $9.4 \%$, a similar result to that carried out in our hospital in the year 1994 in which the percentage of Maxillofacial Surgery admissions was $11.3 \% .^{5}$ In addition to this, a third of the patients attended in the Emergency Unit were later seen in our department.

\section{Conclusions}

According to the study carried out in our hospital we can conclude that: the most common age range of patients attended was 0 to 10, and the majority of patients that attended the Emergency Unit were men. The day with most pressure for assistance was Sundays, and the month with the greatest number of emergencies and admissions was June. The etiology resulting in most visits to the Emergency Unit were accidents, and trauma represents the maxillofacial pathology with the greatest demand for emergency care in our hospital. The most common treatment carried out immediately was medical. 